\title{
Improving Writing Skills by Using Guided Questioning Techniques Through Film Media
}

\author{
Rulli Saragi*, Feni Susana Eky, Ariance Ana Lasibey \\ Tourism Department \\ Kupang State Polytechnic \\ Kupang, Indonesia \\ *rulli.saragi@pnk.ac.id, ekyfeny@gmail.com, rinlasibey@gmail.com
}

\begin{abstract}
The objectives of this study is to describe the improvement of writing skills for the second semester students of the Hospitality Study Program, Department of Tourism, Kupang State Polytechnic. This study used a classroom action research design. Conducted in two cycles, namely cycle I and cycle II. The research subject is the skill of writing narrative paragraphs in semester II A students of the Hospitality Study Program, Department of Tourism, Kupang State Polytechnic. The techniques in this study used test and non-test techniques. The data collection technique in cycle I and cycle II used quantitative techniques for the test results of writing narrative paragraphs and non-test results using qualitative techniques. The results showed that the class average value in the first cycle reached 64.53 or in the sufficient category and increased in the second cycle to 82.73 or in the good category. In cycle I and cycle II increased by 11.6. Learning to write narrative paragraphs using the guided questioning technique through film media has been implemented well so that it can improve the skills of writing narrative paragraphs for second semester students of the Hospitality Study Program, Department of Tourism, Kupang State Polytechnic. Based on the results of this study, it is suggested that Indonesian language teaching staff should be more creative in choosing the right learning techniques, one of which is to use guided questioning techniques through film media as an alternative in facilitating the teaching learning process.
\end{abstract}

Keywords—narrative paragraph, guided question, film

\section{INTRODUCTION}

Writing skills must be possessed by a student because writing is one of the competencies that must be achieved in learning in the world of education. The problems associated with learning Report Writing (Indonesian) occurs in semester II A students (of the Hospitality Study Program, Department of Tourism, Kupang State Polytechnic). Based on the results of the writing of the semester 2 A students (of the Hospitality Study Program, Department of Tourism, Kupang State Polytechnic), the researcher concluded that the writing ability is still less than 80 . The average semester score is 65 with the highest score of 75 and the lowest score of 58. Relating to the writing ability of semester II A students Hospitality Study Program, Department of Tourism, Kupang State Polytechnic, there are problems that are at the core of all existing problems, namely with regard to learning techniques and effective media to make it easier for students to practice writing reports. This research is important to do as an effort to find innovative techniques as an alternative to solving the problem of low writing skills of second semester students' report writing skills in the Hospitality Study Program, Department of Tourism, Kupang State Polytechnic.

Based on the description above, the problem in this research is how to improve writing skills in semester II A of the Hospitality Study Program, Department of Tourism, Kupang State Polytechnic by using guided questioning techniques through film media. Therefore, this research was conducted with the aim of describing the improvement of writing skills of students in semester II A of the Hospitality Study Program, Department of Tourism, Kupang State Polytechnic using guided questioning techniques through film media.

\section{LITERATURE REVIEW}

Writing is a language skill that is used to communicate indirectly, not face to face with other people. Writing is a productive and expressive activity. In writing activities, a writer must take advantage of graphology, language structure and vocabulary. This writing skill will not come automatically but must go through many and regular practices and questions [1].

A paragraph is as a series of sentences that are interconnected and form a unitary subject matter [2]. While paragraphs are a group of sentences that are interconnected and together explain a thought that is expressed in the entire writing [3]. As well as dividing paragraphs into deduction paragraphs, induction paragraphs, mixed paragraphs. A deduction paragraph is a paragraph whose main idea lies at the beginning of the paragraph.

Narrative paragraphs are stories [3]. The narrative paragraph aims to tell or tell, emphasizing order and usually a character is being told. A narrative paragraph is a type of paragraph commonly used by writers to tell about a series of 
events or events that develop through time [4]. In other words, narration is a type of paragraph or process. Narrative is a form of writing that seeks to create, narrate, thread the actions of human beings in an event chronologically or that takes place in a certain time unit. A narrative paragraph is a collection of events arranged in a time sequence or sequence of events [5]. Narrative is usually written based on observation. The form of narrative writing is preferred in learning because narrative paragraphs are a type of paragraph that aims to tell a subject. The type of narrative paragraph that is often used in writing narrative paragraphs is Expository narrative, where the expository narrative is generalization, which is a narrative that conveys a general process, which can be done by anyone and can be repeated. Carrying out that type of incident repeatedly, one will gain high proficiency in it. An example of a narrative about a person who tells how to make fried rice, and suggestive is a narrative in the form of an action or deed that is linked in an incident or event. The whole series of events took place in a single time. But the main goal or goal is not to expand one's knowledge, but to try to give meaning to the event or incident as an experience [6].

The questioning technique is a good teaching method to ask a certain set of questions, besides that it can also be used to gain dexterity, accuracy, opportunity, and skills [7]. In addition, guidance is assistance or special demands given to students by paying attention to the potential that exists in these students so that they can develop as much as possible [8]. The expected learning situation from the guided questioning technique is: 1) active listening to the teacher's explanation, 2) active students during the learning process of writing narrative paragraphs, and 3) active work on assignments given by the teacher. The advantages of film as a medium of learning are as follows: 1) Films can complement the basic experiences of students when they read, discuss, practice, and so on. Films are a substitute for the natural surroundings and can show objects that normally cannot be seen, such as how the heart works when it beats. 2) film can describe a process precisely which can be witnessed repeatedly if deemed necessary. 3) in addition to encouraging and increasing motivation, films instill attitudes and other affective aspects. 4) Films that contain positive values can invite thought and discussion in student groups. 5) Films can present dangerous events when viewed directly, such as volcanic lava or wild animal behaviour. 6) Films can be shown to large and small groups, heterogeneous groups, and individuals. 7) With the capabilities and techniques of frameby-frame shooting, a film that takes one week in normal speed can be shown in a minute or two [9].

The method of this study taken from several journals. The idea of using guiding questions is from journal of Research in English and Education (READ) [10] and Unila Journal of English Teaching (U-JET) [11], which have same purpose, but focused on different aspects. The study of READ and U-JET focused on general aspects such as content, organization, vocabulary. Language use, mechanic, while this study focused on more specific aspects such as action of events, time and place, chronological events, completeness of story element, spelling usage, and tidiness of writing. According to the study results of READ and U-JET stated that by using guided questions technique, the students more focused on the aspects of writing and the writing skill of the students got improved.

The idea of using film is taken from English Language Teaching (ELT) [12] and Humaniora [13], which have same purpose and same media that is film, but focused on different aspects. ELT and Humaniora focused on grammar, vocabulary, content, mechanics, and organization, while this study focused on action of events, time and place, chronological events, completeness of story element, spelling usage, and tidiness of writing. The result of both studies showed that by using film media, the students were motivated to focus on the writing aspects and their writing skill got improved.

\section{METHODS}

This type of research is classroom action research. This research was conducted by the Hospitality Study Program Class II A Kupang State Polytechnic Academic Year 2019/2020 with three cycles. Each cycle consists of four aspects. Four aspects in classroom action research, namely; planning, acting, observing, and reflecting [14]. The subject of this research is the skill of writing narrative paragraphs of the second semester students of the Hospitality Study Program. The data source is the second semester A Hospitality Study Program student at the Kupang State Polytechnic with a total of 30 students, consisting of 12 male students and 18 female students.

Data collection techniques used in this study are; 1) the test technique is that students are asked to write narrative paragraphs using guided questioning techniques through film media by paying attention to actions or events, time and place, chronology of events, completeness of story elements (plot, characters and characterizations, setting, mandate), use of spelling and neatness of writing. 2) non-test techniques, namely to determine the process and changes in student behaviour in the learning process of writing narrative paragraphs. The data collected in this study used non-test techniques in the form of observation guidelines, daily notes, interviews, teacher and student guidelines and documentation in the form of photos. The data analysis techniques used in this research are quantitative techniques and qualitative techniques. There is also a formula used to calculate the cumulative score from all aspects, calculate the class average score, and calculate the percentage, namely:

$$
\mathrm{SP}=\underline{\mathrm{SK}} \times 100 \%
$$

$\mathrm{R}$

Note:

SP: Percentage score

SK: Cumulative score

R: Number of respondents 


\section{RESULTS}

\section{A. Cycle I Research Results}

This research begins with the first cycle of action which is carried out as an effort to improve and solve the problem of writing narrative paragraphs faced by students consisting of test results and non-test results. The test results are the test scores of narrative paragraph writing skills using guided question techniques through film media. Non-test results include observations, daily notes, interviews, and documentation.

\section{B. Improving Narrative Paragraph Writing Skills by Using Questioning Techniques Guided through Film Media in Cycle I}

The results of the first cycle test are preliminary data for the implementation of learning to write narrative paragraphs using guided questioning techniques through film media. The results of writing narrative paragraphs are based on six aspects that must be considered in writing narrative paragraphs. The six aspects include: (1) action or event, (2) time and place, (3) chronology of events, (4) completeness of story elements (characters and characterizations), (5) use of spelling, (6) neatness of writing. The number of students who took the first cycle test was 30 students. The results of writing narrative paragraphs using guided questioning techniques through the first cycle of film media can be seen in table 1 below.

TABLE I. RESUlT OF NARRATIVE PARAGRAPH WRITING SKILl OF CYCLE 1

\begin{tabular}{|c|c|c|c|c|c|}
\hline Category & $\begin{array}{l}\text { Score } \\
\text { Range }\end{array}$ & $\begin{array}{c}\text { Frequen } \\
\text { cy }\end{array}$ & Score & $\begin{array}{c}\text { Percentage } \\
(\%)\end{array}$ & $\begin{array}{c}\text { Average } \\
\text { Score }\end{array}$ \\
\hline The Best & $85-100$ & 0 & 0 & 0 & \multirow{5}{*}{$\begin{array}{l}\frac{1936 \times 100}{30} \times 10 \\
=64,53 \\
\text { (Enough) }\end{array}$} \\
\hline Good & $70-84$ & 12 & 854 & 40 & \\
\hline Enough & $60-69$ & 15 & 1019 & 50 & \\
\hline Low & $0-59$ & 3 & 63 & 10 & \\
\hline Total & & 30 & 1936 & 100 & \\
\hline
\end{tabular}

The data in Table 1 shows that the results of the test of narrative paragraph writing skills using guided questioning techniques through film media reached a total value of 1936 with an average of 64.53. These results represent the total score of six aspects of narrative paragraph writing skills that have been tested, namely actions or events, time and place, chronology of events, completeness of story elements (plot, characters and characterizations, setting, mandate), use of spelling, and neatness of writing.

In learning to write narrative paragraphs using guided questioning techniques through film media, student achievement can also be seen from the percentage in each aspect. This percentage describes the achievement of each aspect of learning in class. The percentage of achievement of each aspect in learning to write narrative paragraphs using guided questioning techniques through the first cycle of film media can be seen in the following table 2 .
TABLE II. AVERAGE GRADES OF STUDENTS'SKILL IN EACH ASPECTS IN NARRATIVE PARAGRAPH WRITING SKILLS TESTING WITH GUIDED QUESTIONING TECHNIQUES THROUGH FILM MEDIA

\begin{tabular}{|l|l|l|}
\hline \multicolumn{1}{|c|}{ Aspect } & \multicolumn{1}{c|}{ Average Score } & Category \\
\hline Action or Event & 63,29 & Enough \\
\hline Time and Place & 65,14 & Enough \\
\hline Chronologilcal events & 68,30 & Enough \\
\hline $\begin{array}{l}\text { Compltenes of story element } \\
\text { (plot,character } \\
\text { characterization, setting, } \\
\text { mandate) }\end{array}$ & 70,57 & Enough \\
\hline Spelling usage & 65,60 & Enough \\
\hline Tidiness of writing & 65,12 & Enough \\
\hline
\end{tabular}

From Table 2, it can be seen that the test of narrative paragraph writing skills using guided questioning techniques through film media in cycle I from each aspect. The first aspect, the action or event achieves an average score of 63.29 or enough category. Thus it can be said that the ability of students in the aspect of action or events has sufficient criteria. The second aspect, time and event achieve an average score of 65.14 or enough categories. The third aspect, chronological elements of the story reach an average score of 68.30 or enough categories. The fourth aspect, the completeness of the story element reaches an average score of 70.57 or enough categories. In the fifth aspect, spelling usage reaches an average score of 65.60 or enough categories. In the sixth aspect, the neatness of the writing reaches an average score of 65.12 or enough categories.

Some students are able to write narrative paragraphs according to the aspects of the action or event as determined, but there are still some students who have not been able to write narrative paragraphs according to the specified aspects. This result is good enough that it should be increased in cycle II.

The low skill of writing narrative paragraphs in the first cycle was due to the lack of student skills in writing narrative paragraphs, difficulty in describing events, timing, chronological events, and the emphasis of characters in stories that were unclear. Students have not been able to describe the scene of the incident and the exact time in the film that was shown and the sentence framework will be written into the narrative paragraph, so that in writing the narrative paragraph is not accurate and still careless. This result still does not meet the target so it must be explained in more depth to students about the time and place of the incident and needs to be improved in cycle II.

The low skill of writing narrative paragraphs in the first cycle was due to the lack of student skills in writing narrative paragraphs, difficulty in describing events, timing, chronological events, and the emphasis of characters in stories that were unclear. Students have not been able to describe the scene of the incident and the exact time in the film that was shown and the sentence framework will be written into the narrative paragraph, so that in writing the narrative paragraph is not accurate and still careless. This result still does not meet 
the target so it must be explained in more depth to students about the time and place of the incident and needs to be improved in cycle II.

\section{Reflection on Cycle I Research Results}

In general, learning to write narrative paragraphs using the guided questioning technique through film media by the teacher can be followed by students well, even though it is still not as expected. There are still some students who are less enthusiastic in learning to write narrative paragraphs and do not pay close attention to teacher orders. Some students who were not initially interested in learning became interested in learning to write narrative paragraphs. Most of the students became more enthusiastic and enthusiastic about participating in learning to write narrative paragraphs because students were helped by screening the film before writing narrative paragraphs. Through the use of guided questions learning strategies through film media in learning to write narrative paragraphs, students gain convenience and get ideas as material for writing narrative paragraphs.

\section{Research Results in Cycle II}

The second cycle of action is a continuation of cycle I. The action is carried out because in the first cycle the results of the writing skills of narrative paragraphs in semester II A of the Hospitality Study Program of Tourism Vocational School of Kupang State Polytechnic are still in the sufficient category with an average of 64.53. These results have not met the specified target of 75 or in a good category. In addition, there were still learning activities that were not running optimally. Students still show negative behaviour during the learning process. Therefore, learning in cycle II was carried out to improve learning deficiencies in cycle I.

\section{E. Improving Narrative Paragraph Writing Skills by Using Guided Questioning Techniques through Film Media}

Based on the test results in the second cycle, there has been an increase in the skills of writing narrative paragraphs with guided questioning techniques through film media in the second semester students of Hospitality Study Program at the Kupang State Polytechnic Tourism Study Program. This increase was influenced by the application of the guided questioning technique through film media which had been improved in cycle II. The aspects assessed in this study include six aspects (1) action or event, (2) time and place, (3) chronology of events, (4) completeness of story elements (plot, character and characterization, setting, mandate), (5) use of spelling, (6) neatness of writing.

\section{F. Narrative Paragraph Writing Test Results Using Guiding Question Techniques through Film Media in Cycle II}

The results of cycle II are the results of the test of writing narrative paragraphs with the guided question technique through the second film media after improvements are made in cycle I. The assessment criteria include six aspects: (1) action or event, (2) time and place, (3) chronology of events, (4) completeness of story elements (plot, character and characterization, setting, mandate), (5) use of spelling, (6) neatness of writing. The table shows the results of the test of narrative paragraph writing skills with guided questioning techniques through film media in cycle II.

TABLE III. RESUlt OF NARRATIVE PARAGRAPH WRITING SKILl OF CYCLE II

\begin{tabular}{|c|c|c|c|c|c|}
\hline Category & $\begin{array}{l}\text { Score } \\
\text { Range }\end{array}$ & $\begin{array}{c}\text { Frequen } \\
\text { cy }\end{array}$ & Score & $\begin{array}{c}\text { Percentage } \\
(\%)\end{array}$ & $\begin{array}{c}\text { Average } \\
\text { Score }\end{array}$ \\
\hline The Best & $85-100$ & 10 & 962 & $33,33 \%$ & \multirow{5}{*}{$\begin{array}{l}\frac{1936}{30} \times 100 \\
=64,53 \\
\text { (Enough) }\end{array}$} \\
\hline Good & $70-84$ & 20 & 1520 & $66,66 \%$ & \\
\hline Enough & $60-69$ & 0 & 0 & 0 & \\
\hline Low & $0-59$ & 0 & 0 & 0 & \\
\hline Total & & 30 & 30 & 2482 & \\
\hline
\end{tabular}

The data in table 3 , shows that the results of the narrative paragraph writing skill test using guided questioning techniques through film media reached a total value of 2482 with an average of 82.73 which was in the good category. From the 30 students, students who obtained a score range between $85-100$ or in the very good category totalled 10 students or $33,33 \%, 20$ students or $66.66 \%$ obtained scores in the good category with a score range of 70-84, as many as 0 students or $0 \%$ scored in the moderate category with a score range of 60-69, no student got scores in the poor category, the score range was 0-59. These results are the total score of six aspects of narrative paragraph writing skills that have been tested, namely aspects of action or events, aspects of time and place, chronological aspects of events, aspects of completeness of story elements (plot, character, characterization, setting, mandate), aspects of spelling usage, and aspects of neatness of writing. So there are 30 students said to be complete. The details of the students' narrative paragraph writing test results for each aspect in cycle II can be seen in Table 4 below.

TABLE IV. AVERAge Grades of StUdents' SKILls IN EACH ASPECT IN NARRATIVE PARAGRAPH Writing SKILlS TESTING WITH GUIDED QUESTIONING TECHNIQUES THROUGH FILM MEDIA

\begin{tabular}{|l|l|l|}
\hline \multicolumn{1}{|c|}{ Aspect } & \multicolumn{1}{|c|}{ Average Score } & Category \\
\hline Action or Event & 75,86 & Good \\
\hline Time and Place & 77,57 & Good \\
\hline Chronologilcal events & 79,10 & Good \\
\hline $\begin{array}{l}\text { Compltenes of story element } \\
\text { (plot,character and } \\
\text { characterization, setting, } \\
\text { mandate) }\end{array}$ & 83,45 & The best \\
\hline Spelling usage & 76,43 & Good \\
\hline Tidiness of writing & 76,50 & Good \\
\hline
\end{tabular}

From table 4 shows the average value of narrative paragraph writing skills using guided questioning techniques through film media on each aspect. The average score of each aspect includes: The action or event aspect reaches an average score of 75.86 or in either category. This value comes in a good 
category. Thus it can be said that the ability of students in the aspect of actions or events that have been determined is good criteria. Aspects of time and place reach an average score of 77.57 or in either category, Chronological aspects of events achieve an average score of 79.10 or in either category, aspects of the completeness of the story elements (plot, character and solidity, setting, mandate) achieve an average score of 83.45 or in an excellent category, the aspect of spelling usage reaches an average score of 76.43 or in a good category, and the neatness aspect of the writing reaches an average score of 76.50 or in a good category.

\section{G. Reflection of Research Result in Cycle II}

Learning to write narrative paragraphs with guided questioning techniques through film media carried out in cycle II was well followed by students. In the learning process, changes in behaviour for the better can be seen. Based on the test and non-test results of students in learning to write narrative paragraphs using guided questioning techniques through film media as a whole, it shows that students are interested in the learning. The use of techniques and media is used to facilitate students in writing narrative paragraphs. Learning like this is fun because students are given the opportunity to exchange ideas in writing narrative paragraphs. Students who are lacking can be helped by using guided questioning techniques through film media. From the test and non-test results that have been achieved by students, the learning process of writing narrative paragraphs in cycle II has been successful so that there is no need for the implementation of the next cycle.

\section{DISCUSSION}

The discussion of the research results in writing narrative paragraphs with guided questioning techniques through film media is based on the first cycle and the results of the second cycle of action. This classroom action research was carried out in two stages, namely cycle I and cycle II. The discussion of the research results includes the process of learning narrative paragraph writing skills with guided questioning techniques through film media, improving narrative paragraph writing skills through film media, and changes in student behaviour after learning to write narrative paragraphs using guided questioning techniques through film media. The discussion of the learning process includes all activities in the classroom when learning to write narrative paragraphs using guided questioning techniques through film media. From the result of each cycle, it was proved that using video could improve students' writing skills. The improvement of narrative paragraph writing skills through film media can be seen from the results of the test cycle I and cycle II, while the change in student behaviour after learning to write narrative paragraphs using guided questioning techniques through film media can be seen from the results of the non-test cycle I and cycle II. The following is a discussion based on the results of the research cycle I and cycle II.
TABLE V. Result of NARRATIVE PARAGRAPH Writing SKILls of CYCLE I AND CYCLE II

\begin{tabular}{|l|c|c|c|c|}
\hline \multirow{2}{*}{ Aspect } & \multicolumn{2}{c|}{$\begin{array}{c}\text { Class Score } \\
\text { Average }\end{array}$} & \multicolumn{2}{c|}{ Improvement } \\
\cline { 2 - 5 } & SI & SII & SII-SI & $\begin{array}{c}\text { Percent } \\
(\%)\end{array}$ \\
\hline Action or Event & 63,29 & 75,86 & 12,57 & 21,10 \\
\hline Time and Place & 65,14 & 77,57 & 12,43 & 17,02 \\
\hline Chronologilcal events & 68,30 & 79,10 & 10,8 & 15,63 \\
\hline $\begin{array}{l}\text { Compltenes of story element } \\
\text { (plot,character and } \\
\text { characterization, } \\
\text { mandate) }\end{array}$ & 70,57 & 83,45 & 12,88 & 15,16 \\
\hline Spelling usage & & & & \\
\hline Tidiness of writing & 65,60 & 76,43 & 10,83 & 16,31 \\
\hline
\end{tabular}

Analysis Data, 2020

Based on Table 5 above classically, the results of the narrative paragraph writing skills test using the guided question technique through film media increased from cycle I to cycle II by $18.2 \%$ from the average grade value in cycle I by 64.53 to 82.73 in cycle II.

The results of the narrative paragraph writing skills test cycle I and cycle II can be explained that the skill of writing narrative paragraphs using question-guided techniques through film media in each aspect is improved. The average score on the action or event aspect of cycle I reached an average of 63.29 and after cycle II learning the average score reached 75.86 , an increase of 12.57 . In terms of time and place the average score obtained in cycle I reached 65.14 and after cycle II learning reached 77.57, an increase of 12.43. In the chronological aspect of the event the average score obtained in cycle I reached 68.30 and after the study cycle II reached 79.10 , an increase of 10.8. In terms of completeness of the story elements the average score obtained in cycle I reached 70.57 and after the learning cycle II reached 83.45, increased by 12.88 , the aspect of spelling usage of the average score obtained in cycle I reached 65.60 , and after cycle II learning reached 76.43, an increase of 10.83, the last neat aspect of the average score in cycle I reached 65.12, and after cycle II reached 76.50, an increase of 18.2.

Based on the above discussion can be concluded that the use of question-guided techniques through film media can assist students in writing narrative paragraphs through film media. This is proven by the absence of test results that fall into the good category. The average value in cycle I of 64.53 or in the category is sufficient and has not reached the specified target. In cycle II it increased by 18.2 to 82.73 in the good category.

\section{CONCLUSIONS AND RECOMMENDATIONS}

Based on the results of research and discussion, it can be concluded as follows: The skills of students in semester II A Tourism Study Program at the Kupang State Polytechnic in writing narrative paragraphs have increased after participating in learning using guided question techniques through film media. Improved narrative paragraph writing skills can be seen 
in the test and non-test results. The test results showed that the class average score in the first cycle was 64.53 , which was categorized as sufficient. In the second cycle the average score of students in writing narrative paragraphs increased to 82,73 in the good category, all students also achieved the research target of 75. This indicates an increase in the average score of students in semester II A Tourism Study Program at the Kupang State Polytechnic. By learning to write narrative paragraphs with guided questioning techniques through film media successfully.

It is recommended that lecturers in the Report Writing course should use the guided questioning technique through film media as an alternative in the implementation of learning to write narrative paragraphs because it has been proven to be able to improve student skills in writing narrative paragraphs and change student behaviour in a positive direction.

\section{REFERENCES}

[1] H.G. Tarigan, Writing As Language Skill. Bandung: Angkasa, 2013.

[2] Dr. Kosasih, Basic Of Writing Skill. Bandung: Yrama Widya, 2012.

[3] A. Wiyanto, Paragraph Writing Skill. Jakarta: Grasindo, 2004.
[4] J.Ch. Sujanto, Language Skill: Reading, Writings, Speaking For General Courses Of Indonesian Language. Jakarta : Depdikbud, 2002.

[5] Subyantoro, Classroom Action Research. Semarang: Undip, 2009.

[6] G. Keraf, Naration, Argument Edition IIII. Jakarta: Gramedia, Pustaka Utama, 2007.

[7] S.B. Djamarah, Teaching Learning Strategy. Jakarta: PT Rineka Cipta, 2010.

[8] S. Arikunto, Education Management. Yogyakarta: Aditya Media, 2008.

[9] A. Arsyad, Media of Learning. Jakarta: Rajawali Pers, 2002.

[10] Firdani and S.S. Fitriani, "Teaching Writing through Guiding Questions Technique to Improve Students' Writing Skill,” Research in English and Education (READ), vol. 2, no. 4, 2017.

[11] Gusparia, Zainil, and Refnaldi, “Improving Students' Writing Skill of Narative Texts by Using Animation Video at Grade XI Science 2 Program of SMA N 1 Teluk Kuantan," Journal English Language Teaching (ELT), vol. 2, no. 2, Juli 2014.

[12] S.T. Imanisa, H. Huzairin, and S. Sudirman, Improving the Students' Ability in Writing Descriptive Text Through Guided Questions Technique at the Second Grade of SMPN 23 Bandar Lampung. Doctoral dissertation, Lampung University, 2017.

[13] S. Siswanjaya, A. Saukah, and F.M. Ivone, "Implementing Guiding Questions Combined with Animation Film to Improve Ninth Graders' Narrative Writing Skill," Jurnal Pendidikan Humaniora, vol. 5, no. 1, pp 33-39, 2017.

[14] Kemmis and Mc. Taggart, The Action Research Planner. Geelong: Deaken University Press, 2010. 